\title{
Partial Characterization and Purification
}

\section{of a Rabbit Granulocyte Factor that \\ Increases Permeability of Escherichia coli}

\author{
Jerrold Weiss, Richard C. Franson, Susan Beckerdite, \\ Katherine Schmemler, and Peter Elsbach \\ From the Department of Medicine, New York University School of Medicine, \\ New York 10016
}

\begin{abstract}
A B S T R A C T Recently we reported that rapid killing of Escherichia coli by granulocytes or granulocyte fractions is accompanied by an equally rapid and discrete increase in permeability of the microbial envelope (Beckerdite, Mooney, Weiss, Franson, and Elsbach. 1974. J. Exp. Med. 140: 396-409). Most of this permeability-increasing activity (PI) is found in a crude granule preparation. PI is quantitatively recovered in a 23,000-g supernatant fraction (Sup II) after sulfuric acid extraction of granulocyte homogenates prepared in water. PI is nondialyzable, destroyed by pronase and trypsin, stable at $4^{\circ} \mathrm{C}$ for at least $2 \mathrm{mo}$, and destroyed by heating at $94^{\circ} \mathrm{C}$. Anionic substances, such as heparin sulfate and isolated $E$. coli lipopolysaccharide, bind to and inhibit PI. PI has been purified up to 1,000 fold from homogenate in a yield of $50 \%$ by acid extraction and carboxymethyl-Sephadex chromatography. Such purified fractions have bactericidal activity that equals that of disrupted granulocytes and Sup II, are similarly enriched with respect to granule-associated phospholipase $A_{2}$ and are devoid of lysozyme, myeloperoxidase, and protease activities. Whereas $E$. coli, sensitive to $\mathrm{PI}$, binds or inactivates solubilized PI, a resistant strain of Serratia marcescens does not. Binding of PI to sensitive microorganisms seems to be necessary for expression of its biological activity since both the apparent binding to and the biological effect of PI on
\end{abstract}

Dr. Franson is a recipient of Public Health Service postdoctoral fellowship I-F-02 AM 54970-1 from the National Institute of Arthritis and Metabolic Diseases. Dr. Elsbach is a career scientist of the Health Research Council of the City of New York (contract I-379).

Received for publication 12 June 1974 and in revised form 26 August 1974.
E. coli are completely blocked by $10-20 \mathrm{mM} \mathrm{Mg}^{2}$ or $\mathrm{Ca}^{2+} . \mathrm{Mg}^{2+}$ or $\mathrm{Ca}^{2+}$ can reverse the effect on $E$. coli permeability produced by Sup II or the carboxymethylSephadex fraction but not that produced by granulocyte homogenate.

The close association of bactericidal, phospholipase $A_{2}$, and permeability-increasing activities towards several gram-negative bacterial species suggests that they may be related.

\section{INTRODUCTION}

Rapid killing of Escherichia coli by granulocytes occurs without gross microbial structural disorganization (1-3), but is associated with a discrete increase in permeability of the microbial envelope that is evident within minutes after the bacteria are exposed to granulocytes or bactericidal granulocyte fractions (4). Several investigators have proposed that the mode of action of bactericidal agents derived from granulocytes $(5,6)$, or other sources $(7,8)$, may include effects on permeability. In some instances an effect on phospholipids has been invoked $(7,9)$.

In this communication we describe the partial purification and characterization of a granulocyte factor that increases the permeability of several species of gram-negative bacteria. A 1,000-fold purified preparation of this activity contains a similarly enriched phospholipase $A_{2}$, as well as most of the bactericidal potency of disrupted granulocytes.

\section{METHODS}

Preparation of granulocytes. Polymorphonuclear leukocytes were obtained from overnight, sterile peritoneal exudates produced in rabbits by injection of glycogen in physiological saline as described previously (10), except that no heparin was added to the collection flask. More than 95\% 
Rabbit granulocyte homogenate $\left(3.0 \times 10^{8}\right.$ granulocyte equivalents $\left./ \mathrm{ml} \mathrm{H}_{2} \mathrm{O}\right)$

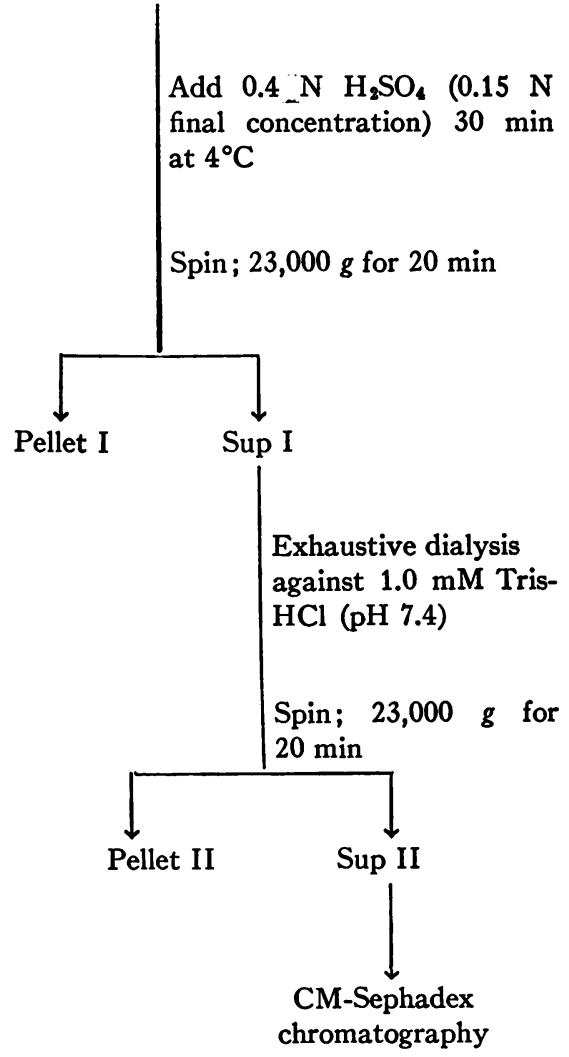

FIGURE 1 Partial purification of PI from rabbit granulocytes.

of the cells were granulocytes as judged by differential cell count. The cells were sedimented by centrifugation at $50 \mathrm{~g}$ for $10 \mathrm{~min}$ and resuspended in the desired medium.

Cell fractionation. The sedimented granulocytes were resuspended in ice-cold $0.34 \mathrm{M}$ sucrose $\left(2.0 \times 10^{8}\right.$ granulocytes $/ \mathrm{ml}$ ) by vigorous pipetting and stored at $4^{\circ} \mathrm{C}$ for 30 min. The cell suspension was then homogenized with a Potter-Elvehjem apparatus and cell disruption was monitored by phase-contrast microscopy. Nuclei and cell debris were removed by centrifugation of the homogenate at $150 \mathrm{~g}$ for $10 \mathrm{~min}$. The $150-g$ supernatant fraction was then subjected to centrifugation at $8,200 \mathrm{~g}$ for $20 \mathrm{~min}$ to yield a crude granule fraction $(8,200-g$ pellet). The $150-g$ pellet and the crude granule pellet were resuspended in $0.34 \mathrm{M}$ sucrose to a final concentration of $2.0 \times 10^{8}$ granulocyte equivalents $/ \mathrm{ml}$.

Extraction of permeability-increasing activity $(P I)^{2}$ (Fig. 1). Sedimented granulocytes were resuspended in distilled water $\left(3.0 \times 10^{8}\right.$ granulocyte equivalents $\left./ \mathrm{ml}\right)$ and ice-cold $0.4 \mathrm{~N} \mathrm{H}_{2} \mathrm{SO}$, was added to a final concentration of $0.15 \mathrm{~N} \mathrm{H}_{2} \mathrm{SO}_{4}$. The extraction, described more fully in a preceding paper (4), yields a supernatant fraction (Sup II)

\footnotetext{
${ }^{1}$ Abbreviations used in this paper: Act D, actinomycin D; CM, carboxymethyl; LPS, lipopolysaccharide; ONPG, onitrophenyl- $\beta$-D-galactopyranoside; PI, permeability-increasing activity; Sup II, supernate II.
}

which contained at least as much biological activity per granulocyte equivalent as the homogenate with less than $5 \%$ of the homogenate protein. Normal rabbit alveolar macrophages $\left(3.0 \times 10^{8}\right.$ cells $\left./ \mathrm{ml}\right)$ were extracted in the same manner. For Sup II preparations of rabbit diaphragm, kidney, liver, and spleen $4.0 \mathrm{~g}$ (wet weight) of tissue was homogenized in $8.0 \mathrm{ml}$ of $0.34 \mathrm{M}$ sucrose and extracted in the same manner. All acid extracts and purified fractions were stored at $4^{\circ} \mathrm{C}$.

Bacteria. E. coli (W) were grown in minimal medium buffered with triethanolamine at $\mathrm{pH}$ 7.75-7.9 and Serratia marcescens were grown in trypticase soy broth (Baltimore Biological Laboratories, Cockeysville, Md.) (4). The bacteria used were obtained from overnight cultures that were transferred to fresh medium and subcultured for approximately $2.5 \mathrm{~h}$ at $37^{\circ} \mathrm{C}$. At this time bacteria were sedimented by centrifugation at $10,000 \mathrm{~g}$ for $10 \mathrm{~min}$ and were resuspended in sterile isotonic saline to the desired concentration.

Measurement of PI. PI was measured by determining the susceptibility of $E$. coli to actinomycin D (Act D), an agent that normally does not cross $E$. coli's permeability barrier (11). Thus, unless indicated otherwise, PI was measured by determining the effect of a given fraction on bacterial $\left[{ }^{14} \mathrm{C}\right]$ leucine incorporation in the presence and absence of Act $D$ as described in a preceding paper (4). A typical incubation mixture contained $2.5 \times 10^{8} \mathrm{E}$. coli (W), 2-8 $\times 10^{8}$ granulocytes (or material derived from this number of cells), $10 \mu \mathrm{mol}$ of Tris-maleate buffer at $\mathrm{pH} 7.5,25 \mu \mathrm{l}$ of Hanks' solution (Hanks' balanced salt solution (without phenol red), Microbiological Associates, Inc., Bethesda, Md.), $250 \mu \mathrm{g}$ of casamino acids mixture (Difco Laboratories, Detroit, Mich.), $\mathrm{L}-\left[1-{ }^{14} \mathrm{C}\right]$ leucine $(0.063$ $\mu \mathrm{Ci}, 0.13 \mathrm{mM}$ ) (ICN Corp., Chemical \& Radioisotopes Div., Irvine, Calif.) and sterile saline to bring the total volume to $0.25 \mathrm{ml}$. Incorporation of $\left[{ }^{14} \mathrm{C}\right]$ leucine into $E$. coli $(\mathrm{W})$ was determined in the presence and absence of $12.5 \mu \mathrm{g}$ of Act $\mathrm{D}$. Cycloheximide was added to all incubation mixtures in a final concentration of $0.5 \mathrm{mM}$ to exclude incorporation of labeled amino acids into granulocyte protein. Incubations were carried out at $37^{\circ} \mathrm{C}$ for $30 \mathrm{~min}$. The reactions were stopped by the addition of $3.0 \mathrm{ml}$ of ice-cold $10 \%$ trichloroacetic acid and the mixtures were filtered and counted as described in a preceding paper (4). For quantitation of PI the following equation was used:

Percent permeability effect of a given granulocyte fraction $=$

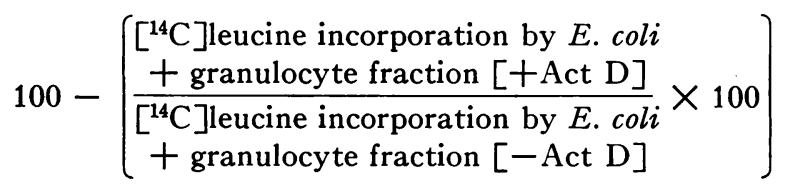

One arbitrary unit of PI has been defined as that amount of activity that produces a $50 \%$ effect (equation). For these calculations, triplicate determinations were carried out with, of a given granulocyte fraction, at least three different concentrations that produce a linear inhibition of $\left[{ }^{14} \mathrm{C}\right]$ leucine incorporation by $E$. coli in the presence of Act $D$ and a constant effect on incorporation in the absence of Act $D$.

Bactericidal activity. Bactericidal activity of a given fraction was measured by taking 10- $\mu$ l samples of the suspensions after $30 \mathrm{~min}$ incubation for determining of bacterial colony-forming units as previously described (12).

Enzyme assays. Phospholipase $\mathrm{A}_{2}$ was assayed by using autoclaved $\left[1-^{14} \mathrm{C}\right]$ oleate-labeled $E$. coli as substrate (13). 
TABLE I

Sedimentation of PI with a Crude Granule Preparation

\begin{tabular}{|c|c|c|c|c|c|c|c|c|}
\hline \multirow[t]{2}{*}{ Fraction } & \multicolumn{2}{|c|}{ PI } & \multicolumn{2}{|c|}{$\beta$-Glucuronidase } & \multicolumn{2}{|c|}{ PLA pH 5.5} & \multicolumn{2}{|c|}{ Protein } \\
\hline & units & $\%$ & units & $\%$ & units & $\%$ & $m g$ & $\%$ \\
\hline Homogenate & 82.5 & 100 & 1,545 & 100 & 23.1 & 100 & 18.3 & 100 \\
\hline $150-g$ pellet & 16.0 & 19 & 242 & 16 & 2.7 & 12 & 3.5 & 13 \\
\hline $8,200-g$ pellet (granules) & 64.4 & 78 & 832 & 53 & 14.0 & 61 & 8.3 & 45 \\
\hline $8,200-g$ supernate & 10.1 & 12 & 350 & 23 & 3.9 & 17 & 5.8 & 32 \\
\hline
\end{tabular}

The fractionation of $2.5 \times 10^{8}$ granulocytes was carried out as described in Methods. PI is expressed as units/ $2.5 \times 10^{8}$ granulocyte equivalents, protein (17) as milligrams $/ 2.5 \times 10^{8}$ granulocyte equivalents, $\beta$-glucuronidase as nanomoles of substrate hydrolyzed $/ 1.5 \mathrm{~h} / 2.5 \times 10^{8}$ granulocyte equivalents, and phospholipase $\mathrm{A}_{2}$ activity (PLA pH 5.5) as nanomoles of free fatty acid released $/ \mathrm{hr} / 2.5 \times 10^{8}$ granulocyte equivalents. Incubation conditions are described in the methods section. Data for quantitation of protein, $\beta$-glucuronidase, and PLA pH 5.5 were obtained by averaging at least two different values in the linear range of the assay system. PI was calculated as described in Methods. Triplicate determinations agreed within 5\%. Percent recoveries were: 109 for PI, 92 for $\beta$-glucuronidase, 90 for phospholipase, and 90 for protein.

Myeloperoxidase was determined by the method of Schultz, Shay, and Gruenstein (14), lysozyme by the method of Shugar (15), and protease activity was measured by using $\left[{ }^{14} \mathrm{C}\right]$ leucine-labeled $E$. coli as substrate (1). Protein was estimated by the optical absorbance at 260 and $280 \mathrm{~nm}$ (16) and by the method of Lowry, Rosebrough, Farr, and Randall (17) with bovine serum albumin as standard. $\beta$-Galactosidase was induced in $E$. coli (W) by using isopropyl- $\beta-D$-thiogalactopyranoside (final concentration $10^{-4}$ $\mathrm{M})$ and was measured using $o$-nitrophenyl- $\beta$-D-galactopyranoside (ONPG) as substrate. The conditions of the assay were as described in a recent paper (4).

The effect of proteolytic enzymes on PI. The conditions for trypsin and pronase proteolysis were as follows: each test tube contained $10 \mathrm{mM} \mathrm{Ca}{ }^{2+}, 50 \mathrm{mM}$ Tris $\mathrm{pH} \mathrm{8.0,} \mathrm{Sup}$ II, and $25 \mu \mathrm{g}$ of trypsin or $50 \mu \mathrm{g}$ of pronase. These mixtures were incubated for $1 \mathrm{~h}$ at room temperature and then assayed for PI. Under these conditions, trypsin or pronase alone had no effect on $\left[{ }^{14} \mathrm{C}\right]$ leucine incorporation into $E$. coli protein in the presence or absence of Act D. In this incubation mixture, Sup II had full permeability-increasing activity in the absence of the protease.

\section{RESULTS}

Purification. The finding that PI can be extracted from whole homogenates with strong acid suggested the possibility that this activity is a basic protein as is the case for other acid-extractable biological activities obtained from leukocytes $(18,19)$. Because these activities have been found to be associated with the leukocyte granules $(18,19)$, we sought preliminary evidence before initiating further purification that might indicate whether or not PI also occurs mainly in a granule-rich fraction. Table I shows that PI is predominantly associated with a crude granule-rich pellet. The distribution of PI appeared to follow that of $\beta$-glucuronidase, a known granule marker enzyme (20), and phospholipase $A_{2}$, which was recently demonstrated to be associated with both the specific and azurophilic granules (13). Disruption of the granule preparation, either by $30 \mathrm{~min}$ incubation at $\mathrm{pH} 3.5$ or by seven cycles of freezing and thawing, did not release PI from the particulate $(23,000-g)$ fraction. From these initial studies, we therefore tentatively concluded that PI was membrane and granule associated.

Although acid extraction of granule preparations has been successful for isolation of a number of cationic proteins $(18,19)$, this was not the case for PI. Table II illustrates that a considerable portion of the recovered PI remained particulate when homogenates or granules resuspended in sucrose were extracted; moreover, $35-50 \%$ of the PI initially present was apparently inactivated by acid treatment. By contrast, PI was almost totally recovered in the supernatant fraction (Sup II) when water homogenates were used. No PI was found in Sup II preparations from the same number of normal rabbit alveolar macrophages or from homogenates of rabbit diaphragm, liver, kidney, or lung.

The partial purification of PI from granulocyte homogenates is presented in Table III and Fig. 2. Sulfuric acid extraction of leukocyte homogenates prepared in water totally solubilized PI with a 30 -fold increase in specific activity. PI in Sup II is nondialyzable, stable for at least $2 \mathrm{mo}$ at $4^{\circ} \mathrm{C}$, destroyed by heat at $94^{\circ} \mathrm{C}$, and inactivated by trypsin and pronase. As has been shown for bactericidal activities associated with cationic proteins $(6,21)$, the anionic substances, heparin sulfate and isolated E. coli lipopolysaccharide (LPS), both bind and block the expression of PI.

PI was purified approximately 1,000 -fold in a yield of $52 \%$ by chromatography of Sup II on carboxymethyl (CM)-Sephadex (Table III). PI was firmly bound by this cation-exchange column and was recovered, as a single peak of activity, by elution with $\mathrm{NaCl}$ (Fig. 2). In contrast to the whole homogenate, this purified fraction (CM fraction) had no detectable lysozyme, pro- 
TABLE II

Recovery of $P I$ in Sulfuric Acid Extracts of Leukocyte Preparations

\begin{tabular}{lcccrrr}
\hline \multicolumn{1}{c}{ Fraction } & \multicolumn{2}{c}{$\begin{array}{c}\text { Homogenate } \\
\text { (water) }\end{array}$} & \multicolumn{2}{c}{ Homogenate } & \multicolumn{2}{c}{ Granules } \\
& units $P I$ & $\%$ & units $P I$ & $\%$ & units $P I$ & $\%$ \\
Homogenate or granules & 75.1 & 100 & 82.5 & 100 & 64.6 & 100 \\
Pellet I & 0.4 & 0.5 & 3.3 & 4.0 & 10.9 & 17.0 \\
Pellet II & 8.1 & 10.8 & 11.7 & 14.2 & 0.0 & 0.0 \\
Sup II & 91.5 & 121.8 & 37.8 & 46.0 & 22.2 & 34.2 \\
\hline
\end{tabular}

Sulfuric acid extraction of sucrose or water homogenates of granulocytes was carried out as described in the methods section. Granule preparations were isolated from $0.34 \mathrm{M}$ sucrose homogenates and were resuspended in $0.34 \mathrm{M}$ sucrose $\left(2.0 \times 10^{8}\right.$ granulocyte equivalents $\left./ \mathrm{ml}\right)$ and extracted in the same manner. PI is defined as units $/ 2.5 \times 10^{8}$ granulocyte equivalents and is calculated as described in Methods.

tease, or myeloperoxidase activities, but it did contain a similarly enriched phospholipase $\mathrm{A}_{2}$ activity known to be predominantly associated with the leukocyte granules (13). In addition, this fraction had potent bactericidal activity. In fact, a comparison of the killing of $1 \times 10^{\circ}$ E. coli (W) by crude homogenate, Sup II, and CM fraction (Table IV) shows that the most purified fraction contained as much cidal activity as the cruder preparations. No other fraction collected from the CM-Sephadex column contained detectable bactericidal activity towards $E$. coli.

Fig. 3 compares the effect of increasing amounts (in granulocyte equivalents) of granulocyte homogenate, Sup II, and the $\mathrm{CM}$ fraction on $\left[{ }^{14} \mathrm{C}\right]$ leucine incorporation by $2.5 \times 10^{8} \mathrm{E}$. coli in the presence and absence of Act D. All three fractions produced a similar dose-dependent inhibition of $\left[{ }^{14} \mathrm{C}\right]$ leucine incorporation by $E$. coli in the presence of Act D when up to $5 \times 10^{\circ}$ granulocyte equivalents $(\geq 50 \quad E$. coli/granulocyte equivalent) of whole homogenate or Sup II or up to $12.5 \times 10^{\circ}$ granulocyte equivalents of the $\mathrm{CM}$ fraction were used. In the absence of Act $D$, however, the effect of each granulocyte fraction on leucine incorporation differs depending on the degree of purity; thus, in the

TABLE III

Purification of PI from Granulocyte Homogenates

\begin{tabular}{|c|c|c|c|c|c|}
\hline Fraction & $\begin{array}{c}\text { Protein } \\
\text { per } \\
2.5 \times 10^{8}\end{array}$ & $\begin{array}{l}\text { PI } \\
\text { granu- } \\
\text { locyte } \\
\text { equiva- } \\
\text { lents }\end{array}$ & Recovery & Sp act & $\begin{array}{c}\text { Increase } \\
\text { in } \\
\text { sp act }\end{array}$ \\
\hline & $m g$ & units & $\%$ & & \\
\hline Homogenate & 87.5 & 75.0 & 100 & 0.83 & - \\
\hline Sup II & 3.7 & 91.4 & 122 & 24.7 & $30 x$ \\
\hline CM fraction & 0.04 & 39.2 & 52 & 958.0 & $1,150 \times$ \\
\hline
\end{tabular}

Protein was estimated by the absorbance at 260 and $280 \mathrm{~nm}$ (16). For each fraction PI was determined by using the standard assay conditions as described in Methods. dose-dependent range, whole homogenate has the greatest inhibitory effect, Sup II less and the CM fraction
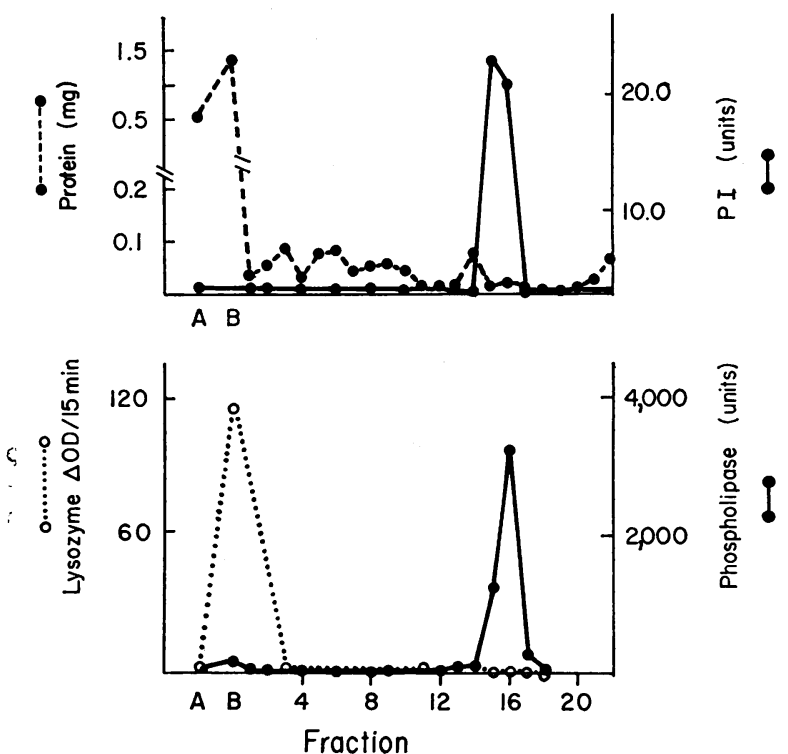

FIgURE 2 Purification of PI by CM-Sephadex chromatography of Sup II. $1.5 \mathrm{ml}$ (2.8 $\mathrm{mg}$ of protein) of Sup II was applied to a CM-Sephadex column $(1 \times 30 \mathrm{~cm})$ equilibrated with $1 \mathrm{mM}$ Tris- $\mathrm{HCl} \mathrm{pH}$ 7.0. Elution was carried out with $30 \mathrm{ml}$ of $1 \mathrm{mM}$ Tris- $\mathrm{HCl}$ buffer, $\mathrm{pH} 7.0$ (fraction A), followed by $30 \mathrm{ml}$ of buffered $0.5 \mathrm{M} \mathrm{NaCl}$ (fraction B), after which $100 \mathrm{ml}$ of a linear $\mathrm{NaCl}$ gradient (0.51.2 M, prepared by use of a Kontes gradient mixer, Kontes Glass Co., Vineland, N. J.) was applied. Fractions A and $B$ were collected in toto; the eluate of the linear $\mathrm{NaCl}$ gradient was collected in $30(3.0-\mathrm{ml})$ fractions. Assays for PI, protein, and lysozyme in individual fractions were carried out by the procedure referred to in the methods section. Phospholipase $\mathrm{A}_{2}$ was measured at both $\mathrm{pH} 5.5$ and at $\mathrm{pH} 7.5$ (13). The elution pattern and enrichment of these two phospholipase activities were identical. The activity in the lower panel refers only to phospholipase activity at $\mathrm{pH}$ 7.5. Total amounts of PI, phospholipase $\mathrm{A}_{2}$, and protein in each fraction assayed are expressed as in Table $I$ and total lysozyme/fraction as $\Delta O D$ at $450 \mathrm{~nm} / 15 \mathrm{~min}$. 
TABLE IV

Killing of E. coli $(W)$ by .Disrupted Granulocytes, Sup II, or CM Fraction as a Function of Concentration of Granulocyte Fraction

\begin{tabular}{lllll}
\hline \multicolumn{1}{c}{ E. coli/granulocyte: } & \multicolumn{1}{c}{$10 / 1$} & $20 / 1$ & $40 / 1$ & $80 / 1$ \\
\hline & & $\%$ survival \\
Disrupted granulocytes & $<0.01$ & 0.4 & 3 & 16 \\
Sup II & $<0.001$ & 0.001 & 0.17 & 0.17 \\
CM fraction & $<0.001$ & 0.05 & 3 & 7 \\
\hline
\end{tabular}

$2.5 \times 10^{8} E$. coli $(\mathrm{W})$ were treated in the standard incubation mixtures with either disrupted granulocytes, Sup II, or CM fraction. The ratios of $E$. coli to granulocyte equivalents werc varied by adjusting the number of granulocyte equivalents of the particular granulocyte fraction while keeping the number of $E$. coli constant. At $30 \mathrm{~min}$, aliquots of the bacterial suspensions were taken, diluted in growth medium, and plated. Colonies were enumerated after incubation at $37^{\circ} \mathrm{C}$ overnight.

none. Because each granulocyte fraction has a different effect on leucine incorporation by $E$. coli in the absence of Act $D$, the inhibitory effect on $\left[{ }^{14} \mathrm{C}\right]$ leucine incorporation specifically attributable to entry of Act D actually is not the same. We define, therefore, PI in a given granulocyte fraction as the difference between $\left[{ }^{14} \mathrm{C}\right]$ leucine incorporation by $E$. coli with and without Act $D$ in the presence of the granulocyte fraction.

In the following sections, the less purified Sup II was often used instead of the more purified fraction for reasons of economy.

Inhibition of PI by $\mathrm{Mg}^{3+}$ or $\mathrm{Ca}^{2+}$. The effect of PI on E. coli is inhibited by increasing concentrations of $\mathrm{Ca}^{2+}$ or $\mathrm{Mg}^{2+2}$ Table $\mathrm{V}$ shows that complete protection of E. coli's permeability barrier is produced at $8-20 \mathrm{mM}$ $\mathrm{Mg}^{2+}$ (or $\mathrm{Ca}^{2+}$, not shown). This protective effect of divalent cation was overcome by adding more PI but was not altered by increasing $E$. coli numbers.

Table VI shows that $\mathrm{Mg}^{2+}$ also effectively prevents loss of viability by $E$. coli exposed to purified PI (CM fraction).

Evidence of Act D penetration is found within 5 min after mixing of $E$. coli and PI (4). The permeability change induced by PI could be reversed by adding $\mathrm{Mg}^{2+}$ up to $20 \mathrm{~min}$ after preincubation of E. coli and PI since subsequent addition of Act $D$ did not cause inhibition of leucine incorporation. Recovery of $E$. coli from the effect of PI by adding $\mathrm{Mg}^{2+}$ (or $\mathrm{Ca}^{2+}$ ) was not seen with granulocyte homogenates, but only with the more purified fractions. This may be explained by the removal, during purification, of other components in the homogenate that act in concert with PI to cause irreversible

\footnotetext{
${ }^{2}$ Other divalent cations $\left(\mathrm{Zn}^{2+}\right.$ and $\left.\mathrm{Mn}^{+}\right)$at $1 \mathrm{mM}$ completely inhibited leucine incorporation by $E$. coli.
}

damage. This contention is supported by the results in Fig. 3 which show that less nonspecific inhibition of leucine incorporation into $E$. coli protein occurs in the absence of Act D with granulocyte fractions of increasing purity.

$\mathrm{Mg}^{2+}$ also inhibits the PI-mediated entry of ONPG into $E$. coli induced for $\beta$-galactosidase (Table VII). Under normal conditions $E$. coli is impermeable to ONPG. In the presence of PI, (whether in Sup II or in CM fraction) ONPG enters $E$. coli and is hydrolyzed by $\beta$-galactosidase, a soluble intracellular $E$. coli enzyme. Complete inhibition of ONPG breakdown is observed at 10-20 $\mathrm{mM} \mathrm{Mg}^{2+}$. Sup II, with or without $\mathrm{Mg}^{2+}$, does not cause leakage of $\beta$-galactosidase (4). $\mathrm{Mg}^{2+}$ alone has no effect on $\beta$-galactosidase activity. One possible explanation for the protection by $\mathrm{Mg}^{2+}$ and $\mathrm{Ca}^{2+}$ against the effect of PI on $E$. coli is that PI interacts with sites on or in the surface of susceptible microorganisms and that this interaction can be prevented by divalent cations. In the next section, experiments will be described that lend support to this supposition.

Apparent binding of PI to susceptible microorganisms. Suspensions of $E$. coli (sensitive to PI) or of $S$. marcescens (resistant to PI) (4), were incubated for $5 \mathrm{~min}$ with Sup II. The suspensions were then subjected to

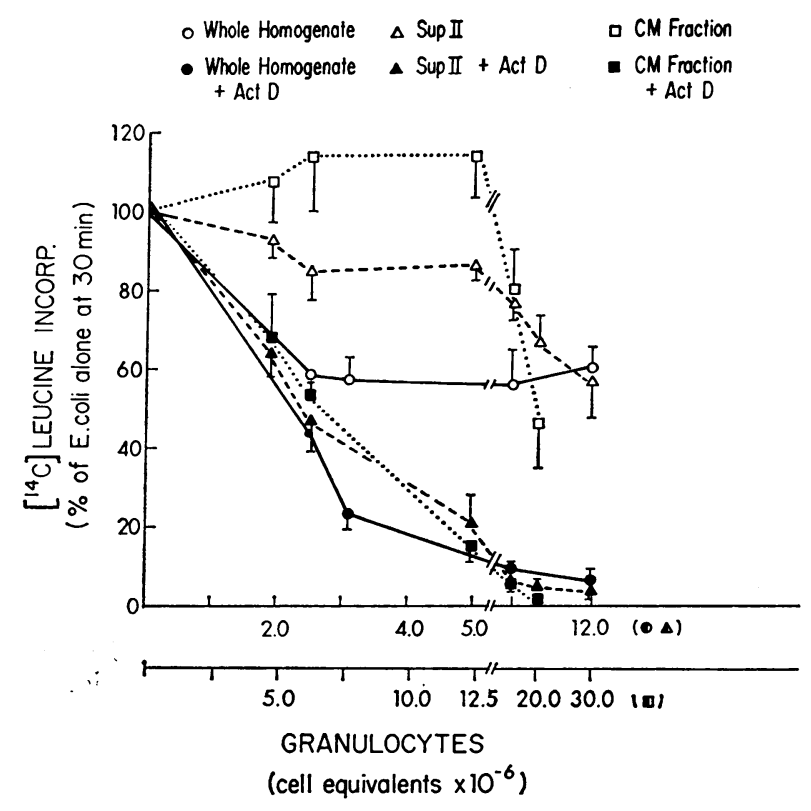

FIgURE 3 Effect of whole homogenate, Sup II, and CM fraction on $\left[{ }^{14} \mathrm{C}\right]$ leucine incorporation by $2.5 \times 10^{8} \mathrm{E}$. coli in the presence and absence of Act D. Incubation conditions were as described in methods. The upper abscissa indicates the amount of whole homogenate or Sup II assayed and the lower abscissa the amount of the CM fraction used, expressed as granulocyte equivalents. Results are shown as mean and standard error of the mean of at least three separate experiments.

Permeability-Increasing Factor of Granulocytes 
TABLE V

Effect of $\mathrm{Mg}^{2+}$ on PI-Induced Susceptibility of E. coli to Act $D$

\begin{tabular}{|c|c|c|c|}
\hline & \multirow[b]{2}{*}{$\mathrm{MgCl}_{2}$} & \multicolumn{2}{|c|}{$\begin{array}{l}{\left[{ }^{\mathscr{C} C}\right] \text { leucine }} \\
\text { incorporation } \\
(\% \text { of } E . \text { coli alone } \\
\text { at } 30 \mathrm{~min})\end{array}$} \\
\hline & & -Act D & +Act D \\
\hline & $m M$ & & \\
\hline \multicolumn{4}{|l|}{ (a) Sup II } \\
\hline E. coli alone & - & 100 & 103 \\
\hline E. coli + Sup II & - & 58 & 6 \\
\hline E. coli + Sup II & 1 & 75 & 35 \\
\hline E. coli + Sup II & 2 & 83 & 51 \\
\hline E. coli + Sup II & 8 & 105 & 90 \\
\hline E. coli + Sup II & 20 & 115 & 118 \\
\hline$E$. coli alone & 20 & 119 & 108 \\
\hline \multicolumn{4}{|l|}{ (b) $\mathrm{CM}$ fraction } \\
\hline E. coli alone & - & 100 & 101 \\
\hline E. coli + CM fraction & 一 & 92 & 11 \\
\hline E. coli + CM fraction & 2 & 106 & 37 \\
\hline E. coli + CM fraction & 8 & 100 & 59 \\
\hline E. coli + CM fraction & 20 & 118 & 124 \\
\hline E. coli alone & 20 & 103 & 110 \\
\hline
\end{tabular}

Increasing concentrations of $\mathrm{MgCl}_{2}$ were added to the standard incubation mixture before adding Sup II $\left(7.0 \times 10^{6}\right.$ granulocyte equivalents) (a) or CM fraction $\left(6.0 \times 10^{6}\right.$ granulocyte equivalents) (b), E. coli (W) $\left(2.5 \times 10^{8}\right)$, Act $\mathrm{D}$, and $\left[{ }^{14} \mathrm{C}\right]$ leucine. Incorporation of $\left[{ }^{14} \mathrm{C}\right]$ leucine into cold trichloroacetic acid-precipitable material is expressed as percent of incorporation by $E$. coli incubated alone for $30 \mathrm{~min}$ $(>8,000 \mathrm{cpm})$.

centrifugation to sediment the bacteria and the supernatant fractions were tested for PI in the usual fashion. Fig. 4 shows that PI was totally recovered in the supernatant fraction of the Serratia suspensions. By contrast, no PI was found in the supernatant fraction of the $E$. coli suspensions. It appears, therefore, that sensitive $E$. coli bound or inactivated PI, whereas the resistant Serratia did not.

In order to demonstrate that apparent binding of PI to a sensitive microorganism is related to expression of the biological effect (i.e., an increase in permeability), a constant amount of Sup II or of CM fraction was preincubated for $5 \mathrm{~min}$ with increasing numbers of $E$. coli. Subsequently, fresh $E$. coli $\left(2.5 \times 10^{8}\right),\left[{ }^{14} \mathrm{C}\right]$ leucine, and Act $\mathrm{D}$ were added to the incubation mixture. Table VIII shows that at very low ratios of $E$. coli to granulocyte equivalents during preincubation most of the PI is subsequently available for interaction with added fresh $E$. coli and near maximal permeability effects are found. However, as the number of $E$. coli in the preincubation mixture is increased more $P I$ is bound and less is available to act on added $E$. coli. Total apparent binding of PI during preincubation is seen when the subsequent $\left[{ }^{14} \mathrm{C}\right]$ leucine incorporation equals that of $E$. coli incubated alone. This occurs at a ratio of $E$. coli to granulocyte equivalents of $20: 1$, roughly corresponding to the ratio at which permeability effects become maximal (see Fig. 3). In fact, comparison of Table VIII and Fig. 3 reveals a remarkably close correlation between the dose dependence of binding of PI to $E$. coli and its effect on permeability.

Furthermore, at $\mathrm{Mg}^{2+}$ concentrations sufficient to protect $E$. coli against the effect of Sup II (or CM-fraction) and Act D, PI is quantitatively recovered in the $10,000-g$ supernatant fraction of the $E$. coli suspension (Table IX). Thus, $\mathrm{Mg}^{2+}$ prevents the apparent binding of PI to $E$. coli at concentrations $(20 \mathrm{mM})$ which maintain both the viability and the normal permeability barrier of $E$. coli to Act D in the presence of PI.

PI also bound to and sedimented with isolated bacterial endotoxin (LPS). However, $\mathrm{Ca}^{2+}$ and $\mathrm{Mg}^{2+}$ (20 $\mathrm{mM}$ ) had no effect on this interaction. These findings suggest that other envelope constituents are important in the interaction of PI with the intact microorganism.

\section{DISCUSSION}

Our findings suggest that the permeability-increasing activity, extracted from rabbit polymorphonuclear leukocytes, resides in a cationic protein or a macromolecule containing a protein moiety necessary for activity.

This factor may well include or be one of the granuleassociated basic proteins described previously by others $(18,19)$. It resembles phagocytin (18) and other bactericidal cationic proteins (19) in its acid extractability, in its inactivation by anionic substances such as heparin and endotoxin, in its resistance to heat, and in its rather similar spectrum and magnitude of bactericidal potency.

TABLE VI

Protection of $\mathrm{E}$. coli by $\mathrm{Mg}^{2+}$ against the Permeability and Bactericidal Effects of the CM Fraction

\begin{tabular}{|c|c|c|c|}
\hline & \multirow{2}{*}{$\begin{array}{l}\text { Colony-forming } \\
\text { units }\end{array}$} & \multicolumn{2}{|c|}{$\begin{array}{l}\quad\left[{ }^{14} \mathrm{C}\right] \text { leucine } \\
\text { incorporation } \\
(\% \text { of } E \text {. coli alone } \\
\text { at } 30 \mathrm{~min})\end{array}$} \\
\hline & & -Act D & +Act D \\
\hline E. coli alone & $5.5 \times 10^{8}$ & 100 & 79 \\
\hline $\begin{array}{l}E . \text { coli }+ \text { CM fraction } \\
E . \text { coli }+ \text { CM fraction }\end{array}$ & $4.2 \times 10^{7}$ & 60 & 8 \\
\hline$+20 \mathrm{mM} \mathrm{MgCl}{ }_{2}$ & $5.4 \times 10^{8}$ & 106 & 78 \\
\hline
\end{tabular}

$1.5 \times 10^{8} \mathrm{E}$. coli $(\mathrm{W})$ were treated in the standard incubation mixture with the $\mathrm{CM}$ fraction $\left(5.0 \times 10^{6}\right.$ granulocyte equivalents) in the presence and absence of $20 \mathrm{mM} \mathrm{MgCl}_{2}$. PI and colony-forming units were determined after a 30 -min incubation as described in Methods. 
However, PI differs in a number of ways from these microbicidal cationic proteins. Thus, PI is not effectively extracted from homogenates prepared in sucrose nor from isolated granules, whether with acid (19) or with a balanced salt solution (18). Reduction of the $\mathrm{pH}$ of granule suspensions to 3.5 releases substantial amounts of phagocytin, but not of PI. Perhaps the most significant difference between PI and both phagocytin and the bactericidal cationic proteins studied by Zeya and Spitznagel (19) is the fact that these compounds lose activity at $4^{\circ} \mathrm{C}$ whereas $\mathrm{PI}$ remains fully active for at least 2 mo at $4^{\circ} \mathrm{C}$.

The ability of $\mathrm{Mg}^{2+}$ or $\mathrm{Ca}^{2+}$ to maintain $E$. coli's normal permeability barrier despite the presence of PI resembles the protection by divalent cations of gramnegative organisms against the growth inhibitory effects of serum $(22,23)$, antibiotics $(24,25)$, drugs (26), and phagocytin (18). The protection afforded by divalent cations against so many widely different factors suggests that the effect is not on a chemical group common to all. The known affinity of certain antibiotics for cations $(27,28)$ as well as the effects of EDTA on the permeability of gram-negative organisms $(29,30)$ raises the possibility that chelation could play a role in the permeability-increasing activity of granulocytes.

Our observations (not shown) indicate that the effects of EDTA on permeability of $E$. coli $(29,30)$ are not the same as those of $\mathrm{PI}$ : we only succeeded in producing a discrete effect of EDTA on $E$. coli permeability (as measured by the effect of Act D on macromolecular synthesis) by strictly adhering to the experimental design of Leive and Kollin (31). Thus, it was necessary to first wash the $E$. coli in $0.12 \mathrm{M}$ Tris buffer before adding EDTA, and then to remove EDTA within 2 min. Any

TABLE VII

Effect of $\mathrm{Mg}^{2+}$ on PI-Induced ONPG Entry into E. coli

\begin{tabular}{lcc}
\hline & $\mathrm{MgCl}_{2}$ & $\begin{array}{c}\text { \% hydrolysis } \\
\text { of ONPG }\end{array}$ \\
\hline E. coli alone & $m M$ & \\
$E$. coli + Sup II & - & 8.8 \\
$E$. coli + Sup II & - & 41.9 \\
$E$. coli + Sup II & 5 & 19.3 \\
$E$. coli + Sup II & 10 & 13.3 \\
E. coli + toluene & 20 & 10.3 \\
E. coli + Sup II + toluene & - & 100.0 \\
& 20 & 100.0 \\
\hline
\end{tabular}

Increasing concentrations of $\mathrm{MgCl}_{2}$ were added to incubation mixtures which contained $2.5 \times 10^{8} \mathrm{E}$. coli induced for $\beta$ galactosidase and $2.5 \mathrm{mM}$ ONPG as substrate. Sup II was then added. Hydrolysis of ONPG is expressed as percent of total activity (toluene-treated cells).

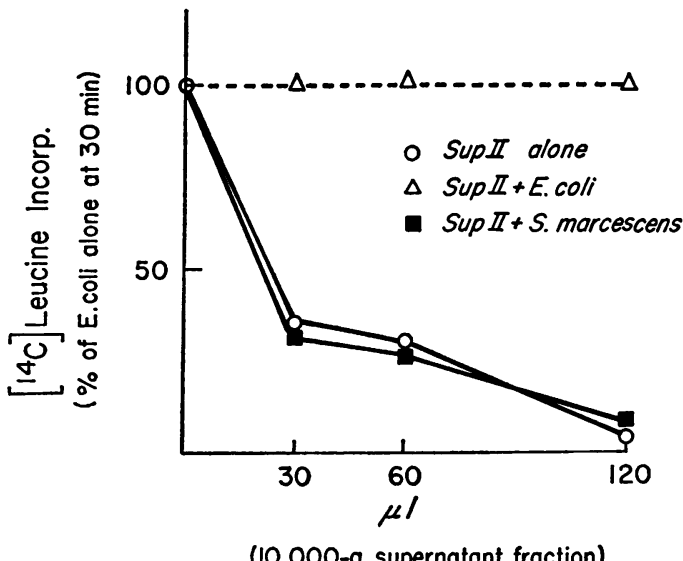

FIgURe 4 Interaction of PI with susceptible and resistant microorganisms. Sup II (from $4 \times 10^{7}$ granulocyte equivalents) was incubated in buffered physiological saline (20 $\mathrm{mM}$ Tris-maleate, $\mathrm{pH} 7.5$ ) alone or with one of two bacterial suspensions: $1.5 \times 10^{\circ} \mathrm{E}$. coli (W) or $1.5 \times 10^{\circ} \mathrm{S}$. marcescens. After thorough mixing for $5 \mathrm{~min}$, the three incubation mixtures were spun at $10,000 \mathrm{~g}$ for $10 \mathrm{~min}$ to sediment the bacteria and each $10,000-g$ supernatant fraction was assayed for PI by using the standard conditions in the presence of Act D.

longer exposure caused general inhibition of macromolecular synthesis. By contrast, the discrete effect of granulocyte extracts is observed for at least $1 \mathrm{~h}$ after addition and does not require pretreatment with or the presence of Tris buffer. Further, we detected no firm binding of ${ }^{25} \mathrm{Ca}^{2+}$ by Sup II, by $E$. coli alone, or by $E$. coli incubated with Sup II. Thus, a chelate interaction between PI, E. coli and $\mathrm{Ca}^{2+}$ (or $\mathrm{Mg}^{2+}$ ) seems unlikely.

On the other hand, weak interaction of organic compounds such as antibiotics with divalent cations may be important determinants in antimicrobial action (32). Such weak interaction could prevent the binding of PI to sensitive microorganisms. Several considerations are in line with this supposition: (a) whereas increasing numbers of $E$. coli do not reduce protection by $\mathrm{Mg}^{2+}$, increasing concentrations of PI can overcome this protection (unpublished observations) ; and (b) we showed in Tables $\mathrm{V}$ and IX that $\mathrm{Mg}^{2+}$ not only prevents the increase in permeability but also permits quantitative recovery of $\mathrm{PI}$ in the medium after incubation with E. coli.

The protection of $E$. coli by $\mathrm{Mg}^{2+}$ (or $\mathrm{Ca}^{2+}$ ) against both the permeability effect and the apparent binding of PI suggests that binding is required for the biological effect. The observation that binding and the permeability effect have a closely similar dose-dependence provides considerable support for this view, as does the finding that a strain of $S$. marcescens that is insensitive to PI

Permeability-Increasing Factor of Granulocytes 
TABLE VIII

Effect of Preincubating PI-Containing Fractions with Increasing Numbers of E. coli

\begin{tabular}{|c|c|c|c|}
\hline \multirow[b]{2}{*}{ Additions during preincubation } & \multirow{2}{*}{$\begin{array}{c}E . \text { coli/ } \\
\text { granulocyte } \\
\text { ratio }\end{array}$} & \multicolumn{2}{|c|}{$\begin{array}{c}{\left[{ }^{14} \mathrm{C}\right] \text { leucine }} \\
\text { incorporation } \\
(\% \text { of } E . \text { coli alone } \\
\text { at } 30 \mathrm{~min})\end{array}$} \\
\hline & & -Act D & +Act D \\
\hline \multicolumn{4}{|l|}{ (a) Sup II } \\
\hline None & - & 100 & 110 \\
\hline Sup II alone & 一 & 72 & 2 \\
\hline Sup II $+1.3 \times 10^{7}$ E. coli & $2: 1$ & 77 & 4 \\
\hline Sup II $+6.3 \times 10^{7}$ E. coli & $10: 1$ & 89 & 9 \\
\hline Sup II + $1.0 \times 10^{8}$ E. coli & $15: 1$ & 99 & 64 \\
\hline Sup II $+1.3 \times 10^{8} E$. coli & $20: 1$ & 108 & 96 \\
\hline Sup II $+2.5 \times 10^{8}$ E. coli & $40: 1$ & 123 & 118 \\
\hline \multicolumn{4}{|l|}{ (b) $\mathrm{CM}$ fraction } \\
\hline None & - & 100 & 96 \\
\hline $\mathrm{CM}$ fraction alone & - & 86 & 12 \\
\hline $\mathrm{CM}$ fraction $+1.9 \times 10^{7} \mathrm{E}$. coli & $3: 1$ & 86 & 18 \\
\hline $\mathrm{CM}$ fraction $+6.0 \times 10^{7} \mathrm{E}$. coli & $10: 1$ & 101 & 30 \\
\hline $\mathrm{CM}$ fraction $+1.0 \times 10^{8} \mathrm{E}$. coli & $17: 1$ & 115 & 73 \\
\hline $\mathrm{CM}$ fraction $+2.0 \times 10^{8} \mathrm{E}$. coli & $33: 1$ & 113 & 99 \\
\hline
\end{tabular}

A constant amount of Sup II $\left(6.6 \times 10^{6}\right.$ granulocyte equivalents) (a) or $\mathrm{CM}$ fraction $\left(6.0 \times 10^{6}\right.$ granulocyte equivalents) $(b)$ was preincubated for $5 \mathrm{~min}$ at $37^{\circ} \mathrm{C}$ with increasing numbers of $E$. coli (W) in physiological saline containing $20 \mathrm{mM}$ Tris-maleate buffer ( $\mathrm{pH} 7.5$ ). Subsequently this preincubated mixture was added to the standard PI assay system (containing $2.5 \times 10^{3}$ fresh $E$. coli) and PI was measured as described in Methods.

does not bind the activity. Differences among microorganisms in binding and/or in biological effect of PI are likely to provide clues about the physical-chemical determinants of interaction in the envelope.

It is widely held that the cytoplasmic membrane of the microbial envelope represents the main permeability barrier, although other barriers within the envelope have been proposed $(29,33)$. The experiments described herein provide no further insight into the location of the barrier. It is of interest, however, that isolated granules, which contain PI in almost totally sedimentable form, readily exert their effect on the microbial envelope. If indeed the permeability change is caused by particle-particle (granule-bacterium) interaction, it is difficult to reconcile such an effect with a permeability barrier deep within the envelope. On the other hand, it has not yet been possible to exclude a transfer of PI from granule membrane to microbial envelope before action on the barrier.

The mode of action of the granulocyte's PI remains undefined but a number of possible mechanisms can be excluded. The preservation of full permeability-increasing and bactericidal activities, of sensitivity of these activities to inhibition by $\mathrm{Mg}^{2+}$ and $\mathrm{Ca}^{2+}$, and of the close correlation of the permeability effect to the dose dependence of binding of PI to $E$. coli in the most purified preparations eliminates the possible contribution of other cationic proteins (such as lysozyme), present in Sup II, to the observed effects. In addition, both protease and myeloperoxidase activities, present in whole homogenate, were absent in the more purified fractions. Because phospholipids probably convey many of the permeability barrier properties to biological membranes, and because phospholipase activity is thought to be associated with other microbicidal compounds (colicine, plakin) (34, 35 ), it is of great interest that the permeability-increasing activity and phospholipase $A_{2}$ activities have, thus far, not been separated despite a 1,000 -fold purification. However, the relationship between these two granuleassociated activities is unclear because very limited $E$. coli phospholipid hydrolysis accompanies the alteration of E. coli's permeability barrier. Yet, the possibility remains that even the limited hydrolysis produced by the granulocyte phospholipase $A_{2}$ is sufficient to alter E. coli's permeability barrier.

Although rid of several biologically active granulocyte constituents, the CM fractions that contain highly purified PI and phospholipase $A_{2}$ also retain full bac-

TABLE IX

Inhibition of PI Binding to E. coli by $\mathrm{Mg}^{2+}$

\begin{tabular}{|c|c|c|}
\hline \multirow{2}{*}{$\begin{array}{l}\text { Supernatant fraction from preincubated } \\
\text { suspensions of: }\end{array}$} & \multicolumn{2}{|c|}{$\begin{array}{l}{ }^{\left[{ }^{4} \mathrm{C}\right] \text { leucine }} \\
\text { incorporation } \\
(\% \text { of } E \text {. coli alone } \\
\text { at } 30 \mathrm{~min})\end{array}$} \\
\hline & -Act D & +Act D \\
\hline \multicolumn{3}{|l|}{ (a) Sup II } \\
\hline E. coli alone & 100 & 96 \\
\hline E. coli + Sup II & 123 & 117 \\
\hline \multicolumn{3}{|l|}{ E. $\operatorname{coli}+$ Sup II } \\
\hline$+20 \mathrm{mM} \mathrm{MgCl}_{2}$ & 88 & 7 \\
\hline Sup II alone & 75 & 4 \\
\hline \multicolumn{3}{|l|}{ (b) $\mathrm{CM}$ fraction } \\
\hline E. coli alone & 100 & 123 \\
\hline E. coli $+\mathrm{CM}$ fraction & 127 & 106 \\
\hline \multicolumn{3}{|l|}{ E. coli $+\mathrm{CM}$ fraction } \\
\hline$+20 \mathrm{mM} \mathrm{MgCl}$ & 75 & 5 \\
\hline $\mathrm{CM}$ fraction alone & 57 & 4 \\
\hline
\end{tabular}

Sup II (1.5 $\times 10^{7}$ granulocyte equivalents) $(a)$ or CM fraction $\left(1.5 \times 10^{7}\right.$ granulocyte equivalents) $(b)$ was preincubated for 5 min at $37^{\circ} \mathrm{C}$ with $5.0 \times 10^{8} \mathrm{E}$. coli (W) in physiological saline containing $20 \mathrm{mM}$ Tris-maleate buffer ( $\mathrm{pH} 7.5$ ) in the presence and absence of $20 \mathrm{mM} \mathrm{MgCl}_{2}$. The mixtures were then subjected to centrifugation at $10,000 \mathrm{~g}$ for $10 \mathrm{~min}$ to sediment the bacteria. The $10,000-g$ supernatant fractions were dialyzed against four changes of $200 \mathrm{vol}$ of $1 \mathrm{mM}$ Tris$\mathrm{HCl}(\mathrm{pH}$ 7.5). The dialyzed fractions were assayed for PI, as described in Methods. 
tericidal activity. Nonetheless it is not yet clear to what extent the rapid increase in permeability contributes to loss of viability of suspectible gram-negative microorganisms. The finding that different strains of Salmonella typhimurium were equally effectively killed by granulocyte extracts, whether or not they became susceptible to Act D (4), suggests that a change in permeability is not absolutely required for loss of viability. It should be recognized, however, that microbial envelopes may differ markedly even within a given species and, therefore, that microbicidal mechanisms may also differ from organism to organism $(2,4)$.

In the case of susceptible bacteria such as $E$. coli it is tempting to view the rapid increase in permeability, possibly induced by granulocyte phospholipase activity, as a critical component of the granulocyte's bactericidal mechanisms. Further purification of the granulocyte factor is necessary to determine whether cidal, phospholipase $A_{2}$, and permeability-increasing activities can be dissociated or not.

\section{ACKNOWLEDGMENTS}

This investigation was supported by Public Health Service grant AM 05472 from the National Institute of Arthritis and Metabolic Diseases, by a grant-in-aid from the New York Heart Association, and by grant U 2381 from the Health Research Council of the City of New York.

\section{REFERENCES}

1. Elsbach, P., P. Pettis, S. Beckerdite, and R. Franson. 1973. Effects of phagocytosis by rabbit granulocytes on macromolecular synthesis and degradation in different species of bacteria. J. Bacteriol. 115: 490-497.

2. Elsbach, P. 1973. On the interaction of phagocytes and micro-organisms. N. Engl. J. Med. 289: 846-852.

3. Elsbach, P., S. Beckerdite, P. Pettis, and R. Franson. 1974. Persistence of regulation of macromolecular synthesis by Escherichia coli during killing by disrupted granulocytes. Infect. Immun. 9: 663-668.

4. Beckerdite, S., C. Mooney, J. Weiss, R. Franson, and P. Elsbach. 1974. Early and discrete changes in permeability of Escherichia coli and certain other gramnegative bacteria during killing by granulocytes. J. Exp. Med. 140: 396-409.

5. Cohn, Z. A. 1963. The fate of bacteria within phagocytic cells. I. The degradation of isotopically labeled bacteria by polymorphonuclear leukocytes and macrophages. J. Exp. Med. 117: 27-42.

6. Zeya, H. I., and J. K. Spitznagel. 1966. Cationic proteins of polymorphonuclear leukocyte lysosomes. II. Composition, properties, and mechanisms of antibacterial action. J. Bacteriol. 91 : 755-762.

7. Hsu Chen, Cheun-Chin, and D. S. Feingold. 1973. The mechanism of Polymixin B action and selectivity toward biologic membranes. Biochemistry. 12: 2105-2111.

8. Feingold, D. S., J. N. Goldman, and H. M. Kuritz. 1968. Locus of the action of serum and the role of lysozyme in the serum bactericidal reaction. J. Bacteriol. 96 : 2118-2126.
9. Wilson, L. A., and J. K. Spitznagel. 1971. Characteristics of complement-dependent release of phospholipid from Escherichia coli. Infect. Immun. 4: 23-28.

10. Elsbach, P., and I. L. Schwartz. 1959. Studies on the sodium and potassium transport in rabbit polymorphonuclear leukocytes. J. Gen. Physiol. 42: 883-898.

11. Hurwitz, J., J. J. Furth, M. Malamy, and M. Alexander. 1962. The role of DNA in RNA synthesis. III. The inhibition of the enzymatic synthesis of RNA and DNA by actinomycin and proflavin. Proc. Natl. Acad. Sci. U. S. A. 48: 1222-1230.

12. Elsbach, P., J. Goldman, and P. Patriarca. 1972. Phospholipid metabolism by phagocytic cells. VI. Observations on the fate of phospholipids of granulocytes and ingested Escherichia coli during phagocytosis. Biochim. Biophys. Acta. 280 : 33-44.

13. Franson, R., P. Patriarca, and P. Elsbach. 1974. Phospholipid metabolism by phagocytic cells. Phospholipases $A_{2}$ associated with rabbit polymorphonuclear leukocyte granules. J. Lipid Res. 15: 380-388.

14. Schultz, J., H. Shay, and M. Gruenstein. 1954. The chemistry of experimental chloroma. I. Porphyrins and peroxidases. Cancer Res. 14: 157-162.

15. Shugar, D. 1952. The measurement of lysozyme activity and the ultra-violet inactivation of lysozyme. Biochim. Biophys. Acta. 8: 302-309.

16. Kalckar, H. M. 1947. Differential spectrophotometry of purine compounds by means of specific enzymes. III. Studies of the enzymes of purine metabolism. J. Biol. Chem. 167 : 461-475.

17. Lowry, O. H., N. J. Rosebrough, A. L. Farr, and R. J. Randall. 1951. Protein measurement with the Folin phenol reagent. J. Biol. Chem. 193: 265-275.

18. Hirsch, J. G. 1956. Phagocytin: a bactericidal substance from polymorphonuclear leukocytes. J. Exp. Med. 103 : $589-611$.

19. Zeya, H. I., and J. K. Spitznagel. 1963. Antibacterial and enzymatic basic proteins from leukocyte lysosomes: Separation and identification. Science (Wash. D. C.). 142: 1085-1087.

20. Cohn, Z. A., and J. G. Hirsch. 1960. The isolation and properties of the specific cytoplasmic granules of rabbit polymorphonuclear leukocytes. J. Exp. Med. 112: 9831004.

21. Hirsch. J. G. 1958. Bactericidal action of histone. J. Exp. Med. 108: 925-944.

22. Reynolds, B. L., and H. Pruul. 1971. Sensitization of complement-resistant smooth gram-negative bacterial strains. Infect. Immun. 3: 365-372.

23. Muschel, L. H., and J. E. Jackson. 1966. Reversal of the bactericidal action of serum by magnesium ion. $J$. Bacteriol. $91: 1399-1402$.

24. Hsu Chen, C. C., and D. S. Feingold. 1972. Locus of divalent cation inhibition of bactericidal action of polymixin B. Antimicrob. Agents Chemother. 2: 331-335.

25. Zunelis, V. M., and G. G. Jackson. 1973. Activity of aminoglycoside antibiotics against Pseudomonas aerugin osa: specificity and site of calcium and magnesium antagonism. J. Infect. Dis. 127: 663-669.

26. Devynck, M. A., P. L. Boquet, P. Fromageot, and E. J. Simon. 1971. The mode of action of levallorphan on Escherichia coli: effects on cellular magnesium. Mol. Pharmacol. 7 : 605-610.

27. Crawford, L. M. 1973. Calcium inhibition of antibacterial activity of kanamycin. Am. J. Vet. Res. 33: 16851688.

Permeability-Increasing Factor of Granulocytes 
28. Albert, A. 1953. Avidity of terramycin and aureomycin for metallic cations. Nature (Lond.). 172: 201.

29. Leive, L. 1968. Studies on the permeability change produced in coliform bacteria by ethylenediaminetetraacetic acid. J. Biol. Chem. 243 : 2373-2380.

30. Leive, L. 1965. Actinomycin sensitivity in Escherichia coli produced by EDTA. Biochem. Biophys. Res. Commun. 18: 13-17.

31. Leive, L., and V. Kollin. 1967. Controlling EDTA treatment to produce permeable Escherichia coli with normal metabolic processes. Biochem. Biophys. Res. Commun. 28 : 229-236.

32. Weinberg, E. D. 1957. The mutual effects of antimicro- bial compounds and metallic cations. Bacteriol. Rev. 21: 46-68.

33. Schnaitman, C. A. 1971. Effect of ethylenediaminetetraacetic acid, Triton X-100, and lysozyme on the morphology and chemical composition of isolated cell walls of Escherichia coli. J. Bacteriol. 108: 553-563.

34. Cavard, D., C. Rampini, E. Barbu, and J. Polonovski. 1968. Activité phospholipasique et autres modifications du métabolisme des phospholipides consecutives a l'action des colicines sur E. coli. Bull. Soc. Chim. Biol. 50: 1455-1471.

35. Higashi, Y., T. Kurimura, O. Kunahara, M. Ozaki, and T. Amano. 1963. Studies on the role of plakin X. Effect on membrane phospholipids. Biken J. 6: 111-126. 